Clark WR, Schmitz RA, Bogenschutz TR. 1999. Site selection and nest success of ringnecked pheasants as a function of location in lowa landscapes. J Wildlife Management 63:976-89.

Chen J, Franklin JF, Spies TA. 1995. Growing-season microclimatic gradients from clearcut edges into old-growth Douglas-fir forest. Agr and Forest Meteorology 63:219-37.

Esseen PA. 1994. Tree mortality patterns after experimental fragmentation of an oldgrowth conifer forest. Biological Conservation 68:19-28.

Ferreira LV, Laurance WF. 1997. Effects of forest fragmentation on mortality and damage of selected trees in Central Amazonia. Conservation Biology 11:797-801.

Forman RT. 1995. Land Mosaics: The Ecology of Landscapes and Regions. Cambridge: Cambridge University Press. $632 \mathrm{p}$.

Goodchild MF, Steyaert LT, Parks BO, et al. (eds.). 1996. GIS and Environmental Modeling. Fort Collins, CO: GIS World. $486 \mathrm{p}$.

Harrison S, Bruna E. 1999. Habitat fragmentation and large-scale conservation: What do we know for sure? Ecography 22:225-32.

Hosmer DW, Lemeshow S. 1989. Applied Logistic Regression. New York: John Wiley \& Sons. $307 \mathrm{p}$.

Landis J, Zhang M. 1998a. The second generation of the California urban futures model. Part 1: Model logic and theory. Environment and Planning A 30:657-66.

Landis J, Zhang M. 1998b. The second generation of the California urban futures model. Part 2: Specification and calibration results of the land-use change submodel. Environment and Planning B: Planning and Design 25:795-824.

Massolo A, Meriggi A. 1998. Factors affecting habitat occupancy by wolves in northern Apennines (northern Italy): A model of habitat suitability. Ecơgraphy 21:97-107.

Merenlender A, Crawford J. 1998. Vineyards in an Oak Landscape: Exploring the Physical, Biological, and Social Benefits of Maintaining and Restoring Native Vegetation in and Around the Vineyard. UC DANR publication 21577. Oakland, CA. 15 p.

Merenlender AM, Heise KL, Brooks C. 1998. Effects of subdividing private property on biodiversity in California's north coast oak woodlands Transactions of the Western Section of the Wildlife Society 34:9-20.

Saunders DA, Hobb RJ, Margules CR. 1991. Biological consequences of ecosystem fragmentation: A review. Conservation Biology 5:18-32.

Sieving KE, Karr JR. 1997. Avian extinction and persistence mechanisms in lowland Panama. In: Laurance WF, Bierregaard R (eds.). Tropical Forest Remnants: Ecology, Management and Conservation of Fragmented Communities. Chicago: University of Chicago Press. p 156-70.

Stouffer PC, Bierregaard RO. 1995. Use of Amazonian forest fragments by understory insectivorous birds: effects of fragment size, surrounding secondary vegetation and time since isolation. Ecology 76:2890-903.

Turner IM. 1996. Species loss in fragments of tropical rain forests: A review of the evidence. J Applied Ecology 33:200-9.

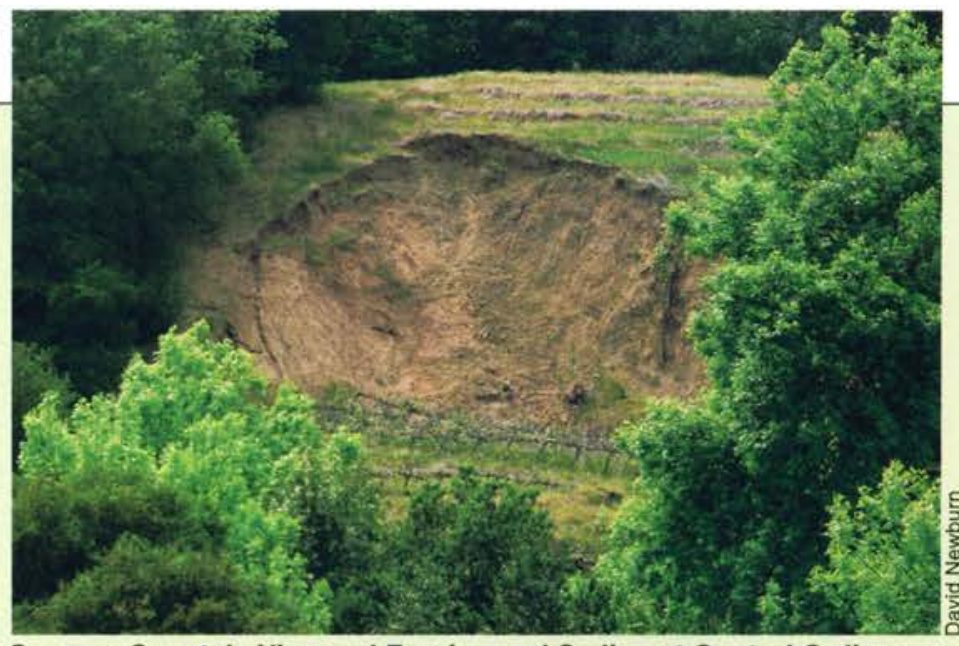

Sonoma County's Vineyard Erosion and Sediment Control Ordinance sets standards for development of new vineyards on certain slopes.

\section{How the GIS was used to map and quantify policy impacts}

\author{
Colin Brooks a Adina M. Merenlender
}

Local regulatory policies addressing vineyard conversion are rapidly evolving in Napa, Lake, Santa Barbara and Sonoma counties. While vineyard development can have an array of effects on forests, watersheds, wetlands, fish and wildlife (Garrison 2000), local policies usually address only soil erosion and water quality. Evolving policies often require farmers to register new vineyard developments with the county, representing some of the first limitations on agricultural development in California.

For an in-depth examination of Sonoma County's local regulations, we used a geographic information system (see GIS box page 8 ) to analyze Sonoma County's Vineyard Erosion and Sediment Control Ordinance adopted in February 2000, which set standards for the development of new vineyards on certain slopes. The purpose was to quantify the areas that would be more and less affected by new regulation, in order to better evaluate the policy and assist decisionmakers.

The Sonoma County ordinance assigns new plantings of vineyards on slopes lower than $15 \%$ (10\% for highly erodible soils) as Level I and requires a 25 -foot stream setback and notification of the agricultural commissioner.
Level II requires a certified erosioncontrol plan for sites averaging between $15 \%$ to $30 \%$ slope (10\% to $15 \%$ for highly erodible soils) and can be prepared by a qualified person with experience in preparing such plans. Level III requires a certified erosioncontrol plan that must be prepared by a qualified professional (such as a registered landscape architect or certified rangeland management specialist). Level III sites are defined as having average slopes from $30 \%$ to $50 \%$ ( $15 \%$ to $50 \%$ for highly erodible soils). Vineyards that fall in Levels II and III must also have a 50 -foot setback from the top of the stream bank, although variances can be applied for. With certain limited exceptions, development on slopes greater than $50 \%$ is prohibited. The ordinance identifies seven soil types as highly erodible. Slope categories for vineyard replantings are treated slightly differently. Our research is focused on potential impacts of future vineyard expansion and does not address replanting levels. The ordinance does not address upland vegetation removal and other habitat conservation issues.

\section{Spatial analysis}

The GIS we developed for vineyards across Sonoma County's land- 


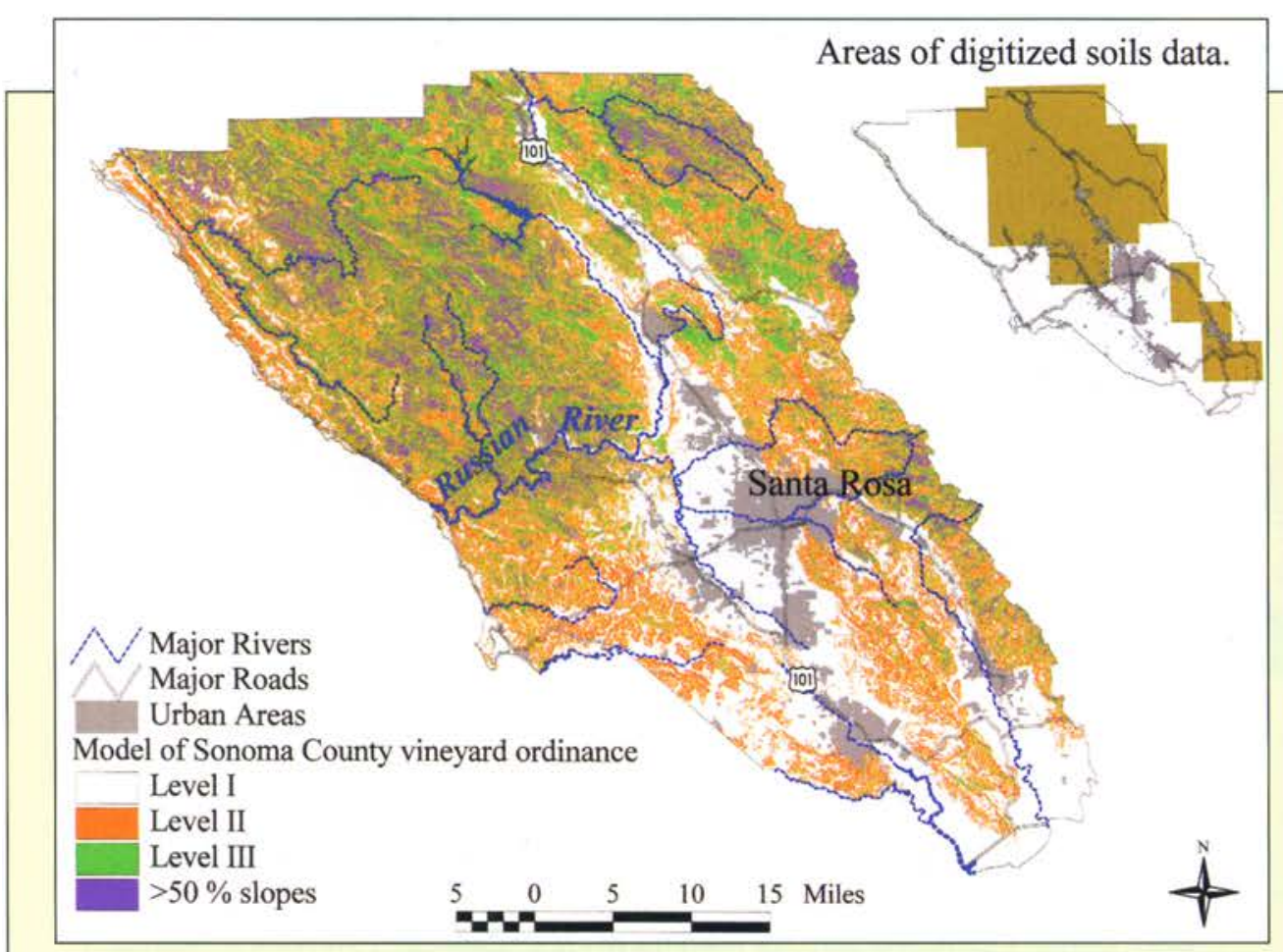

Fig. 1. Model of vineyard ordinance for Sonoma County, using soils data where available.

scape (see p. 7) enabled us to evaluate these new regulations. We mapped those parts of Sonoma County that fell into the three levels defined by the Vineyard Erosion and Sediment Control Ordinance. We wanted to examine areas that would be more and less affected by this policy and quantify the amount of current and possible future vineyard areas that fall into the various levels of regulatory requirements.

We mapped areas that fall into each

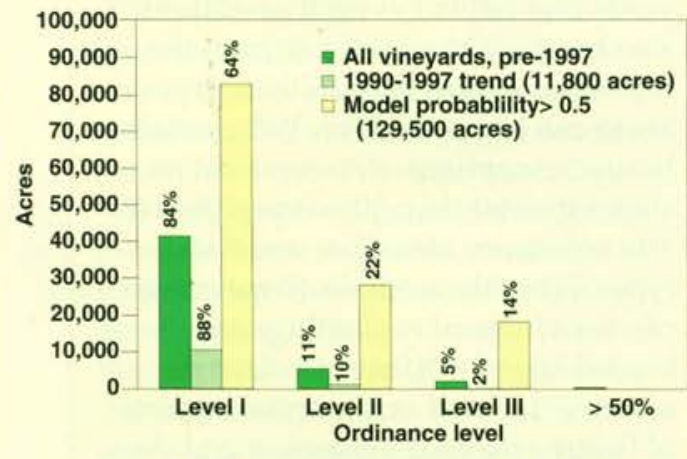

Fig. 2 The percent acreage that falls into each ordinance Level mapped in Figure 1 is presented. Level I requires notifying the agricultural commissioners office and a 25-foot stream set back, Level II and III requires a certified erosion control plan for sites on slopes averaging between $15 \%$ and $30 \%$ slope $(10-15 \%$ for highly erodible soils) and 50 -foot stream set backs (see text for greater detail). regulatory level for new plantings defined in the Sonoma County ordinance (fig. 1). Where we had digitized soils data into a GIS format, these levels reflect whether or not the site is on erodible soils; otherwise, the site was analyzed based on slope class alone. For the entire 1,015,179 acres of Sonoma County, 38\% fall into Level I, 23\% into Level II, and $28 \%$ into Level III. About $11 \%$ have slopes greater than $50 \%$.

We used a digital layer showing vineyard locations established through mid-1997 (see p. 7), which allowed us to calculate how much of this vineyard land would fall into the various regulatory levels if the policy had been in place at the time these vineyards were established. In this case, less than $1 \%$ of the vineyards established prior to 1997 were planted on sites that would have been entirely restricted by the proposed policy (slopes greater than $50 \%)$; very few ( $5 \%$ ) would require Level III regulations, and only slightly more $(11 \%)$ would require Level II regulations.

To estimate the percentage of plantable acreage left that falls under this ordinance, we began with the amount of acreage that was planted from June 1990 through June 1997, or
11,663 acres. We made the assumption that the same number of acres will be developed from 1998 through 2005 a conservative estimate of growth since projects totaling close to 9,000 acres had been submitted to the agricultural commissioner's office by the end of 1999 (Press Democrat Jan. 15, 2000). Using the model we built to map undeveloped areas that are similar to existing vineyards (see p. 12), we mapped the most probable 11,663 acres that are as yet undeveloped. The areas likely to be developed, if vineyard development continues, fall into the levels of the ordinance in a fashion similar to the already developed vineyards (fig. 2), in that $84 \%$ fall into relatively flat areas subject to Level I regulations.

We also examined how future areas for vineyard development will be affected by the Sonoma County ordinance by calculating the areas that fall into the different slope categories (Levels I, II and III) for all of the acres mapped as having a relative probability of being suitable for vineyards greater than 0.5 in our model (see p. 12).

We conclude that most future vineyard development in Sonoma County will fall under Level I and no more than $36 \%$ of future vineyard development, and more likely closer to $20 \%$, will fall under the more stringent regulations requiring 50 -feet setbacks and an erosion-control plan. Before the ordinance was adopted, we provided analysis to the committee that developed the ordinance, the board of supervisors and the public. We hope continued use of this approach assists the public and policy-makers to quantify the implications of policies for agricultural development and environmental protection.

For more information on local policies, see http://danr.ucop.edu/ihrmp

\section{Reference}

Garrison BA. 2000. A Strategy for Conserving Oak Woodlands in Vineyard Landscapes. California Department of Fish and Game Draft Report. 36 p. 